Acta Universitatis

Nicolai Copernici

Zabytkoznawstwo i Konserwatorstwo XLII, Torun 2011

Juliusz Raczkowski

Zakład Historii Sztuki Średniowiecznej i Nowożytnej UMK

\title{
Dawny „ołtarz ambonowy” \\ w kościele pw. Matki Boskiej Różańcowej \\ w Boguszynach w kontekście ostatnich prac konserwatorskich
}

WTościele parafialnym w Boguszynach (niem. Gottberg) w gminie Pełczyce (pow. choszczeński) na Pomorzu Zachodnim znajduja się pozostałości luterańskiego „ołtarza ambonowego” (il. 1-2), stanowiące jeden z licznych przykładów dzieł poreformacyjnych, jakie dotrwały do naszych czasów, dając świadectwo przemian historycznych i religijnych na ziemiach Polski Północnej. Ten snycerski ołtarz, o nowożytnej wprawdzie metryce, ale kryjący w sobie pozostałości gotyckie, przechodził kilkakrotnie strukturalne przekształcenia, podążające za zmianami w obrębie potrzeb liturgicznych gmin wyznaniowych, użytkujących kościół. Niniejszy komunikat ma na celu wprowadzenie zabytku do literatury jako przykładu dzieła „żyjącego”, dostosowywanego do różnych kontekstów i potrzeb, okazją zaś do podjęcia tego tematu stały się przeprowadzone w 2010 roku prace konserwatorskie ${ }^{1}$, których efektem było

1 Prace konserwatorskie przeprowadzili konserwatorzy dyplomowani mgr Agnieszka Przepióra i mgr Michał Ziemkiewicz, badania specjalistyczne wykonał mgr Adam Cupa (ZTiTM IZiK UMK); przy rekonstrukcji elementów rzeźbiarskich współpracował mgr sztuki Dawid Kurkowski. Autor artykułu był konsultantem 
przywrócenie ołtarzowi - przynajmniej w pewnej mierze - utraconego na przestrzeni wieków oddziaływania artystycznego. Prezentowany artykuł jest też przyczynkiem do poruszanego w ostatnich latach problemu konserwatorskiego, jakim są transformacje obiektów zabytkowych w służbie różnych konfesji i stosunek współczesnej konserwacji i ochrony zabytków do owych przekształceń.

Kościół w Boguszynach, murowany z cegły, o salowej nawie nakrytej płaskim stropem, powstał u schyłku średniowiecza - pierwszy pleban został odnotowany w 1492 roku $^{2}$. Najstarszym elementem wyposażenia świątyni był zachowany do dziś dzwon z 1555 roku o cechach gotyckich, odlany przez stargardzkiego ludwisarza Joachima Karstedego (być może już w czasach protestanckich) ${ }^{3}$. Z późniejszego okresu pochodził, odnotowany w inwentaryzacji Hugona Lemckego w 1906 roku, reformacyjny wystrój wnętrza ${ }^{4}$ - oprócz omawianego ołtarza, także empora organowa, empora boczna ze spiralnymi kolumnami z około 1700 roku, dwa XVIII-wieczne, cynowe świeczniki ołtarzowe, dębowa skrzynia z okuciami oraz olejny obraz na desce z XVIII-wiecznego epitafium (portret oficera).

Z tego wyposażenia przetrwało niewiele. Ołtarz snycerski i korpus ambony, obydwa o cechach manierystycznych, stanowią obecnie dwie niezależne części wyposażenia kościoła (do niedawna ambona była funkcjonalnym destruktem). Także pierwotnie elementy te funkcjonowały osobno, nim - jak poświadcza Lemcke - scalono je w charakterystyczny dla dojrzałego luteranizmu ołtarz ambonowy. Manierystyczne retabulum, dawniej być może trójkondygnacyjne, jest obecnie trzyosiową, czte-

z zakresu historii sztuki. Dokumentacja w posiadaniu archiwum parafii oraz Wojewódzkiego Urzędu Ochrony Zabytków w Szczecinie; zob. Dokumentacja prac konserwatorskich i restauratorskich przy manierystycznym ołtarzu głównym z I ćwierci XVII wieku wraz z dwoma rzeźbami gotyckimi, dodanymi elementami neogotyckiego prospektu organowego oraz przy fragmencie korpusu ambony z kościoła pw. Matki Boskiej Różańcowej w Boguszynach, Toruń 2010.

2 H. Lemcke, Bau- und Kunstdenkmäler des Regierungsbezirks Stettin, H. 7: Kreis Pyritz, Stettin 1906, s. 355.

3 M. Majewski, Ludwisarstwo stargardzkie XVI-XVII wieku. Praycaynek do „Corpusu Campanulorum Pomeranorum”, [w:] Mała Ojçyzna - wczoraj i dzis. Materiaty z sesji, Stargard 1999, s. 63.

4 H. Lemcke, op. cit., s. 355-356. 
rokolumnową konstrukcją architektoniczna, złożona z predelli, nastawy i zwieńczenia. Całość ma dość przysadziste proporcje, typowe dla Pomorza, gdzie reformacyjne wyposażanie wprowadzono często do niskich, gotyckich budowli ${ }^{5}$. Pierwszą kondygnację konstrukcji stanowi niska predella, dzielona kolumienkami, zaopatrzona po bokach w krótkie, wolutowe uszaki. Pomiędzy kolumienkami znajdują się płytkie nisze, w których być może były umiejscowione figury. Cokół predelli jest zdobiony fryzem z owalnych kaboszonów i drobnych konsol; cztery wsporniki artykułuja też gzyms predelli. W jej centrum - w polu o kształcie poziomego prostokąta - znajdował się niegdyś odnotowany przez Lemckego relief, przedstawiajacy Ostatnia Wieczerzę. Element ten nie dotrwał do naszych czasów; jego boki były ujęte płaskimi listwami, zdobionymi drobnym ornamentem okuciowym, wykonanym w bardzo płaskim reliefie.

Zasadnicza część nastawy, osadzona na cokole dekorowanym plastycznymi rautami i kaboszonami, ma formę trójosiowej tablicy, w której dwie wąskie, dość płytkie nisze o półkolistym rzucie, zwieńczone drobnymi muszlowymi konchami, flankuja pole o kształcie pionowego prostokąta. Jego pierwotne wypełnienie nie jest znane, ale na podstawie typologii i ikonografii ołtarzy protestanckich z tego czasu można domyślać się, że stanowił je obraz z wyobrażeniem Ukrayżowania, korespondujący z Ostatniq Wieczerz̨ w kontekście eucharystycznej ofiary ${ }^{6}$. Boki nastawy są ujęte w rozbudowane uszaki z ornamentem rollwerkowo-okuciowym, rzeźbionym płasko i jednoplanowo, ale dość precyzyjnie, z powtarzajacym się motywem woluty (il. 3). W ornament są wkomponowane motywy kiści owoców i kobiece maski, a ponad uszakami osadzone pełnoplastyczne, półnagie popiersia, ustawione profilem: po lewej - brodatego mężczyzny, po prawej - kobiety, w wieńcach na głowach ${ }^{7}$. Na bocznych krawędziach uszaków są zamocowane niewielkie obeliski, zdobione rau-

5 H. Mai, Der evangelische Kanzelaltar. Geschichte und Bedeutung, Halle 1969, s. 60. Tendencję do horyzontalizmu w nastawach pomorskich podkreśla także M. Wisłocki, Sztuka protestancka na Pomorzu 1535-1684 (Biblioteka Naukowa Muzeum Narodowego w Szczecinie, seria: „Historia Sztuki”), Szczecin 2005, s. 66.

6 Byłby to przykład programu ikonograficznego, typowego dla luterańskich nastaw na Pomorzu Zachodnim: M. Wisłocki, Sztuka protestancka, s. 74.

7 Być może są to wyobrażenia Adama i Ewy, dopełniające pierwotny, konfesyjny program ołtarza. 
tami i ornamentem okuciowym. Cztery smukłe kolumny, przewiązane przepaską w jednej trzeciej wysokości, ustawione po bokach centralnego pola nastawy, dźwigają ciężar rozbudowanego, gierowanego belkowania, dzielonego czterema wspornikami. Boczne przestrzenie pomiędzy nimi zdobią główki kobiece w fantazyjnych chustach oraz cztery stylizowane maski lwów o groteskowo wykrzywionych pyskach.

Ponad gzymsem belkowania - jak można wnioskować z zachowanych analogicznych zabytków z terenów Pomorza Zachodniego - znajdowała się niegdyś jeszcze jedna kondygnacja. Była to zapewne niewysoka, jednoosiowa tablica wieńcząca, zaopatrzona w uszaki, którą w bliżej nieokreślonym czasie usunięto. Obecny szczyt ołtarza, o formie zbliżonej do trójkąta, powstał przez zestawienie - najpewniej wtórne - dwóch osobnych części snycerskich. Najprawdopodobniej były to owe uszaki trzeciej kondygnacji, po zestawieniu ukoronowane z grubsza dopasowanym, prymitywnie opracowanym zwieńczeniem w formie krzyża ${ }^{8}$. Nie wiadomo, czy zredukowanie ołtarza o jedną kondygnację świadczy o tym, że został on przeniesiony do Boguszyn z innego wnętrza, czy też o ewentualnym obniżeniu pułapu kościoła jeszcze przed 1906 rokiem (Lemcke opisuje znaną nam dziś postać nastawy i o jej redukcji nie wspomina). Jako przykład zbliżonej, w pełni rozbudowanej struktury można przywołać architektoniczną nastawę snycerską w kościele w pobliskich Bolewicach (il. 4), zapewne późniejszą, ale o podobnych formach (z dwupłaszczyznowo potraktowanym ornamentem okuciowo-rollwerkowym), której górna kondygnacja jest ozdobiona zachowanym do dziś, reliefowym przedstawieniem Chrystusa Zmartwychwstałego?

Konstrukcja boguszyńska, w całości bogato polichromowana i złocona, stanowiła przykład jednej z pierwszych formuł protestanckiej nastawy na Pomorzu Zachodnim - wielokondygnacyjnego ołtarza architektonicznego. Ten „samodzielny”, wyzwolony od wcześniejszej tradycji gotyckiej

8 Szczegóły technicznego opracowania obecnego zwieńczenia były dobrze czytelne podczas prac konserwatorskich, w chwili obecnej całość została optycznie scalona, a krzyż zastapiono nowym.

9 Był to jeden z częstszych motywów ikonograficznych w zwieńczeniach ołtarzy protestanckich. M. Wisłocki, Sztuka protestancka, s. 76, nazywa to przedstawienie „ideowym zwornikiem programu” kościoła luterańskiego. 
typ pojawił się na tych terenach na przełomie XVI i XVII wieku, wraz ze wzrostem liczby nowych fundacji $1^{10}$. Ołtarz boguszyński można datować na pierwszą ćwierć XVII wieku (w tym okresie uczytelniła się tendencja do wprowadzania w polach bocznych ołtarzy nisz z figurami ${ }^{11}$ ), zalicza się on więc do najwcześniejszych realizacji tej formuły. Takie datowanie potwierdza charakter ornamentu i motywów zdobniczych, a także stylistyka popiersi figuralnych. Zastosowana tu, wyraźnie niderlandyzująca forma była charakterystyczna dla warsztatów zachodniopomorskich w tym okresie, a przejmowano ją za pośrednictwem warsztatów niderlandzkich, pracujących w Meklemburgii, albo z niderlandzkich i niemieckich wzorników graficznych $^{12}$.

Do tej samej fazy stylistycznej wydaje się należeć również zachowany w dość dobrym stanie korpus ambony. Był on niegdyś zapewne częścią konstrukcji przyściennej (najprawdopodobniej podpartej) o wielobocznym rzucie, który podczas adaptacji do ołtarza zredukowano do trzech ścianek czołowych korpusu. Ambona jest zaopatrzona w masywny cokół, zdobiony rautami i kaboszonami oraz $\mathrm{w}$ rodzaj belkowania $\mathrm{z}$ kartuszami rollwerkowymi. Poszczególne ścianki, oddzielone narożnymi kolumienkami, zdobia plastyczne edikule, zwieńczone naszczytnikami wspartymi na wolutowych wspornikach z dekoracją akantową lub okuciową. Półkoliste pola edikul były zapewne niegdyś wypełnione przedstawieniami malarski$\mathrm{mi}^{13}$. W trójkątnych naszczytnikach widnieja dość miękko modelowane, uskrzydlone główki pucołowatych puttów, o krótkich, ale plastycznych grzywkach ponad czołem. Z tego samego okresu pochodziła także niezachowana empora organowa, opisana przez Lemckego jako „dem Altar ähnlich, in guten Renaissanceformen"14.

$10 \quad \mathrm{Na}$ temat ewolucji form ołtarzy, $\mathrm{z}$ uwzględnieniem typów przejściowych i znaczenia manierystycznych nastaw wielokondygnacyjnych, zob. ibidem, s. 63-68.

11 Ibidem, s. 66.

12 Ibidem, s. 65.

13 Badania technologiczne oraz reflektografia UV ani podczerwień nie wykazały niestety istnienia oryginalnej warstwy malarskiej w tych partiach, więc program ikonograficzny ambony nie daje się odtworzyć.

14 H. Lemcke, op. cit., s. 356. 
W bliżej nieokreślonym czasie ambona i retabulum zostały scalone, tworząc tzw. ołtarz ambonowy, który można zaliczyć do wyróżnionego przez Hartmuta Maia typu „architektonische Kanzelaltar"15. Pod względem ideowym konstrukcje takie były spełnieniem dążności do zespolenia dwóch centrów liturgii protestanckiej ${ }^{16}$. Ołtarze ambonowe pojawiły się w wyposażeniu luterańskich kościołów zachodniopomorskich dopiero pod koniec XVII stulecia ${ }^{17}$. Marcin Wisłocki przytacza przykłady zarówno nowych fundacji, występujących od końca XVII wieku, jak i wtórnego włączania ambony w nowe konstrukcje czy scalania istniejących wcześniej obiektów do nowej formy (jak np. w Ognicy koło Gryfina) ${ }^{18}$. Exemplum tej ostatniej praktyki jest transformacja, dokonana w Boguszynach, o której wtórności informował już Lemcke. Jest ona czytelna także dzięki analizie konstrukcji ołtarza, wykazującej docelowe przeróbki dawniejszej struktury. Ołtarz został pozbawiony centralnego panneau, w którego miejsce wycięto prostokątny otwór, wykrawając też w jego szerokości partię cokołu, jak również gzymsu centralnej kondygnacji ${ }^{19}$. W tak powstałej przestrzeni umieszczono korpus ambony, pozbawiony podstawy $\mathrm{i}-$ jak już wspomniano - zredukowany do trzech tylko ścianek. Nie wiadomo, w jakich dokładnie okolicznościach przeprowadzono te zabiegi - zapewne nastapiło to po 1700 roku, kiedy to ołtarze ambonowe stały się popularne na obszarze nadbałtyckim ${ }^{20}$. Warto zwrócić uwagę, że także wzmiankowany ołtarz w pobliskich Bolewicach zachował ślady podobnej, wtórnej ingerencji ${ }^{21}$. W bliżej nieznanym okresie - ale zapewne bez związku z omówionymi zabiegami - cały ołtarz został pokryty olejnym przemalowaniem, nad którym ubolewał Lemcke (a więc doszło do tego przed początkiem

5 H. Mai, op. cit., s. 19.

16 M. Wisłocki, Sztuka protestancka, s. 95. Na temat teologicznego sensu ołtarzy amonowych w okresie nowożytnym zob. także H. Mai, op. cit., s. 149-155.

17 M. Wisłocki, Sztuka protestancka, s. 95.

18 Ibidem.

19 Obecne przedłużenie linii cokołu i gzymsu w partii centralnej to efekt snycerskiej rekonstrukcji konserwatorskiej z 2010 r., o czym dalej.

20 H. Mai, op. cit., s. 60.

21 Wydaje się, że centralna przestrzeń, wypełniona współcześnie obrazem Matki Boskiej Częstochowskiej, została w pewnym okresie przepruta, przy czym wycięto też fragment partii cokołowej i zmieniono kształt belkowania. 
$\mathrm{XX}$ wieku). Badania wykazały, że była to warstwa brązy, dającej odnotowany przez Lemckego żółtawy odcień.

Kolejna faza przekształceń w obrębie retabulum w Boguszynach wiąże się z rekatolicyzacją kościoła (po 1947 roku). Omawiany zabytek jest jednym z wielu przykładów inwazyjnej praktyki adaptacyjnej, jaka dotknęła w okresie powojennym większość poewangelickich wyposażeń. Problem owych masowych, powojennych modyfikacji stanowi istotne zagadnienie konserwatorskie. Dla terenów Pomorza Wschodniego został on przywołany i przestudiowany przez Joannę M. Arszyńską ${ }^{22}$, bywa też sygnalizowany w odniesieniu do zabytków, zachowanych na innych ziemiach odzyskanych ${ }^{23}$. Ołtarz w Boguszynach jest ciekawym świadectwem owych pospiesznie dokonywanych, brutalnych nieraz adaptacji (il. 5). Po usunięciu korpusu ambony w centralna przestrzeń wprowadzono prymitywny parapet, na którym ustawiono odlaną z gipsu figurę Chrystusa (w popu-

22 Zob. m.in. J. M. Arszyńska, Conservation problems of the common heritage in Poland. The transformed $16^{\text {th }}-18^{\text {th }}$ century Protestant retables in Catholic churches, [w:] Retables in situ. Conservation \& restauration. 11 $1^{\text {es }}$ journées d'etudes de la SFIIC, Roubaix, 24-25.06.2004, s. 49-57; eadem, Empora i tawa patronacka z 1633 roku w kościele parafialnym w Lankiejmach - prayketad powojennych losów zabytków squtuki protestanckiej i problem konserwatorski, „Teka Komisji Historii Sztuki”, t. 10: Materialy sesji nankowej pośnięconej pamięci Prof. Gwido Chmarzyńskiego w traydziesta rocznice śmierci, 12-14 XII 2003, pod red. J. Poklewskiego, Toruń 2005, s. 297-306; J. M. Arszyńska, M. R. Gogolin, Trudne driedzictwoluterańskie zabytki w kościołach mazurskich. Zarys problematyki konserwatorskiej na wybranych praykktadach, „Biuletyn Historii Sztuki”, 2008, nr 3-4, s. 407-434; J. M. Arszyńska, Przeksztatcenia przestrzeni we wnetrzach kościołów luteranskich w dawnych Prusach W schodnich po zmianie ich kontekstu wyznaniowego, [w:] Aktualne problemy konserwatorskie Gdańska, materiały sesyjne, z. 4: Przemiany funk.cii budowli sakralnych w XX w., Gdańsk 2008, s. 12 -18; eadem, Kościót św. Jerzego w Pastęeu - praycsynek do rozważan nad wielokulturowościa miasta, [w:] Aktualne problemy konserwatorskie Gdańska, materiały sesyjne, z. 5: Malowidła kościoła gotyckiego w Mariance - stan dzisiejszy, perspek.tywy, Gdańsk 2009, s. 56-59; eadem, Przeksztatcenia oltarzy w kościołach protestanckich po zmianie ich praynależności konfesyjnej; na prayktadach wybranych zabytków z terenu dawnych Prus W schodnich, [w:] Zabytkowa stolarka we wnetrzach sakralnych i jej problematyka konserwatorska, pod red. J. Krawczyka, Toruń 2010, s. 123-139.

23 Zob. I. Solisz, Problematyka konserwatorska ottaryy ambonowych w dawnych kościotach ewangelickich powiatu kluczborskiego, [w:] Zabytkowa stolarka, s. 181-189; K. Juchniewicz, Ottarz ambonowy w poewangelickim kościele w Ujściu koto Pity - problematyka historyczno-artystyczna $i$ konserwatorska, [w:] ibidem, s. 191-196. 
larnym typie Serca Jezusowego), w późniejszym czasie (po 1991 roku) zastąpiony gipsową figurą Matki Bożej ${ }^{24}$. W szerokość niszy wmontowano ostrołukową arkadę piszczałkową, zaadaptowaną z neogotyckiego prospektu organowego; neogotyckim fryzem ze zwieńczenia szafy organowej zwieńczono gzyms ołtarza ${ }^{25}$. Usunięto środkowa część predelli (il. 6; relief z Ostatnia Wieczerza przepadł zapewne bezpowrotnie), umieszczając tam dwudrzwiową skrzynię tabernakulum oraz dwie elektryczne wieczne lampki. Ołtarz oraz ambona (il. 7) zostały też w całości pokryte kolejnym przemalowaniem farbą olejna, tym razem o odcieniu jasnobrazzowym. Ta wtórna warstwa została nałożona grubo i prymitywnie, z pozostawieniem śladów pędzla (il. 8). W znacznej mierze zatarło to formę i klasę obiektów - być może dlatego ani zabytki z Boguszyn, ani wspomniany ołtarz w Bolewicach (przemalowany z kolei na biało) nie wzbudzały większego zainteresowana badaczy sztuki protestanckiej na północy.

W takiej postaci ołtarz i ambona funkcjonowały aż do 2010 roku, kiedy zespół konserwatorski stanął przed trudnym zadaniem: z jednej strony - przywrócenia historycznej świetności dziełu o burzliwych kolejach losu i zniekształconej kilkakrotnie formie, z drugiej - utrzymania jego katolickiej funkcji liturgicznej. Do standardowych zabiegów należały: odtworzenie ubytków formy oraz reintegracja złoceń i polichromii, opartej na kontrastowym zestawieniu czerwieni i błękitu, której ślady - jak się okazało - zachowały się w dobrym stanie pod warstwą ugrowych przemalowań. Poważniejsza, konceptualna kwestia był natomiast problem rozwiązania centralnej partii nastawy, przed którym konserwatorzy stanęli po usunięciu kultowej „aranżacji” z figurą Madonny pod neogotyckim łukiem. Wmontowanie w tę część korpusu ambony i przywrócenie rzadkiej formy „ołtarza ambonowego" nie było możliwe z przyczyn ideowych. Odrestaurowany korpus kazalnicy, na którym także zrekonstruowano pierwot-

24 Figura Chrystusa widnieje na fotografii i w opisie w karcie inwentarzowej obiektu z 1991 r., sporządzonej przez mgr K. Kalitę-Skwirzyńską.

25 Informacje o pochodzeniu tych elementów z prospektu zaczerpnięto z dokumentu: „Wykaz zabytków ruchomych wpisanych do rejestru zabytków pod numerem B-83, dot. elementów zabytkowego wyposażenia kościoła pw. Matki Boskiej Różańcowej w Boguszynach”, z dn. 17.03.2009, sygn. przez Zachodniopomorskiego Wojewódzkiego Konserwatora Zabytków, Ewę Stanecką. 
ną polichromię i złocenia, został podwyższony i zaadaptowany do swej dawnej funkcji (obecnie jest ustawiony w prezbiterium po stronie lekcji). W przypadku samego retabulum zdecydowano się natomiast na odtworzenie jego stanu pierwotnego, rekonstruując wycięte niegdyś partie poziome gzymsu i cokołu na podstawie zachowanych elementów, w centrum osadzając zaś protestanckie przedstawienie Ukryyżowania ${ }^{26}$. Gotyckie figury zostały przestawione, by optycznie scalić całość kompozycji. W efekcie tych zabiegów dzisiejsze retabulum podąża za formą najbardziej pierwotną, z pierwszej ćwierci XVII wieku. Nie zawiera już w swej strukturze wizualnego przekazu na temat ambonowej funkcji, jaką mu z biegiem czasu nadała protestancka gmina Boguszyn, kumulując w tej szczególnej postaci swą dojrzałą, luterańską tożsamość religijną. Zachowując centralne miejsce w kościele Matki Boskiej Różańcowej, manierystyczny ołtarz wydaje się za to umiarkowanym kompromisem pomiędzy swą protestancką historią a katolickim ususem.

Uwagę przykuwają też gotyckie figury snycerskie nieznanej proweniencji, wtórnie wkomponowane w nisze omawianego retabulum. Przedstawiają one Madonnę z Dzieciątkiem (il. 9) oraz św. Barbarę z modelem wieży (il. 10). Te niepublikowane dotąd zabytki nie zostały jeszcze trafnie rozpoznane pod względem stylowym, co jest istotne wobec dość skromnego stanu zachowania plastyki gotyckiej na Pomorzu Zachodnim. Lemcke określił je ogólnie jako średniowieczne ${ }^{27}$, w dokumentacji Urzędu Konserwatorskiego w Szczecinie są datowane na pierwszą ćwierć XVI wie$\mathrm{ku}^{28}$. Zarówno podczas ingerencji przed 1906 rokiem, jak i przy okazji powojennej „restauracji” retabulum rzeźby zostały pokryte - wraz z cała resztą ołtarza - olejnymi przemalowaniami. Współcześnie przeprowadzone prace konserwatorskie ujawniły istnienie pod tymi warstwami śladów

26 Jest to tymczasowo umieszczona w ołtarzu reprodukcja obrazu $\mathrm{z}$ lat ok. $1630-1640$.

27 H. Lemcke, op. cit., s. 356.

28 Tzw. białe karty zabytków: „Rzeźba - św. Barbara” oraz „Rzeźba - Matka Boska z Dzieciątkiem”, data i nr rejestru marzec 2009, B-83, oprac. mgr Dorota Bartosz, 10.03.2009. 
pierwotnej, gotyckiej polichromii, złoceń i laserunków na srebrze ${ }^{29}$, na podstawie których - decyzją komisji konserwatorskiej - wykończenie to zostało zrekonstruowane.

Zachowane figury są rzeźbione półplastycznie, każda z połowy kloca drewnianego, z tyłu - od podstawy aż do szczytów koron - głęboko wydrążone. O tożsamości wykonawstwa trudno ostatecznie wyrokować - różnice w opracowaniu twarzy i włosów, a także nieco twardszy modelunek pofałdowań szat u św. Barbary wywołują tu pewne wattpliwości. Mimo to obie figury mieszczą się w tej samej, nieco zmanieryzowanej konwencji, standaryzującej rozwiązania stylu pięknego. Ukoronowane, idealizowane postaci cechują się smukłymi proporcjami i zbliżoną budową (owalne głowy na krótkich szyjach, bardzo wąskie, opadające ramiona, krótkie korpusy, wydłużona partia nóg). Są ustawione w esowatych, nieco chwiejnych optycznie pozach, z rękoma trzymanymi blisko przy ciele. U obu zwraca uwagę charakterystyczny, nieco nieanatomiczny sposób wyeksponowania ugiętego kolana nogi balansującej. Niewiasty są odziane analogicznie - w długie przepasane suknie, promieniście sfałdowane ponad paskiem (u Madonny pasek musiał być wykonany osobno i dodany ${ }^{30}$, u paska świętej podrzeźbiono sprzączkę). Spięte z przodu płaszcze (u św. Barbary zawieszony na krótkiej tasiemce) gładko przylegają w partii ramion oraz torsu i spływają ku dołowi w załamujących się dość twardo fałdach, które kumulują się na podstawie jako gęste, głębiej drążone układy. Suchy modelunek i słaba plastyczność draperii, a także ich drobne, powtarzające się pofałdowania (jak np. szereg twardo rzeźbionych niecek) pozwalaja wstępnie określić metrykę rzeźb na około 1430 rok.

Matka Boża podtrzymuje na lewej ręce dość sztywno upozowane nagie Dzieciątko o skrzyżowanych nóźkach, trzymające w rączkach jabłko. Jej płaszcz jest rozchylony i podebrany po obu stronach. Z prawej ręki

29 Próbki zostały poddane analizie mikrochemicznej oraz spektrograficznej, zob. A. Cupa, Badania próbek warstw malarskich z rzeźb z ołtarza oraz z ambony z kościoła pw. Matki Boskiej Różańcowej w Boguszynach, Toruń 2010 [mps w posiadaniu archiwum parafii w Boguszynach oraz Wojewódzkiego Urzędu Ochrony Zabytków w Szczecinie].

30 Układ pofałdowań sukni w partii talii Madonny oraz analogie z epoki sugerują istnienie tego elementu, który niestety nie dotrwał do naszych czasów. 
płaszcz spływa płaska, regularną kaskada, podczas gdy na lewym boku lekko podebrana poła układa się w zaostrzone niecki i ukośnie opada ku dołowi. Odsłonięcie niemal całej sukni Madonny odwołuje się pośrednio do typu „Madonny w otwartym płaszczu”, popularnego w XIV wieku ${ }^{31}$. Nie bez znaczenia była tu zapewne forma rzeźbionego osobno, niezachowanego paska (być może dodanego jako metalowa aplikacja), symbolizującego Dziewicze Macierzyństwo ${ }^{32}$. Układ postaci Jezusa i sposób ujmowania przezeń owocu zdają się utrzymane w tradycji Pięknych Madonn. Odwołuje się do niej także ideał urody Marii i próba oddania cielesności Dzieciątka przez zaznaczenie licznych fałdek tłuszczu na rączkach i nóżkach. Prawa ręka Marii, ugięta w łokciu blisko przy ciele, ujmuje jabłko. Ten prezentacyjny wariant, nawiązujący do starszej tradycji ikonograficznej, upowszechnił się w dziełach stylu pięknego po 1400 roku. Wariant z charakterystycznym zdwojeniem atrybutu był znany w rzeźbie czeskiej i śląskiej, a na północy upowszechnił się być może dzięki napływowi konkretnych wzorców z południa ${ }^{33}$.

Twarz Marii, ujęta szeroko sfałdowanym maforium, cechuje się pewnym stopniem indywidualizmu. Owal jest wydłużony, o wysokim czole (którego wielkość wzmacnia brak plastycznie uformowanych łuków brwiowych) i o drobnej spiczastej bródce. Efekt pociagłości potęuje też opracowanie włosów jako gładkich, wąskich zakoli po bokach twarzy. Rysy są dość regularne - nos długi i prosty, o plastycznych, wyeksponowanych skrzydełkach, usta - wyjątkowo pełne i szerokie. Niewielkie, płytko osadzone oczy charakteryzują się silnie uwypukloną powieką dolna, dająca

31 L. Schultes, Die Marienfigur von Schinckau und der Admont-Freiburger Madonnentypus, [w:] Gotika v západnich echach (1230-1530). Sborník prïspèvkè z. mezinárodního védeckého symposia. Vènováno k. 70. narozeninám Prof. Ph Dr Jaromira Homolky, Praha 1998, s. 33-41.

32 O symbolice wyeksponowanego paska o opadającym do dołu krańcu w rzeźbie statuarycznej zob. przykładowo J. Schmoll gen. Eisenwerth, Lothringische Madonnen-Statuetten des 14. Jahrhunderts, [w:] Kunsthistorische Studie. Festschrift Friedrich Gerke (Variae Formae Veritas Una), Baden-Baden 1962, s. 119-148, zwł. s. 134-135.

33 Na temat tego wariantu ikonograficznego i jego recepcji w rzeźbie północnej zob. m.in. M. Jakubek-Raczkowska, Ržeźba gdańska prz̨etomu XIV i XV wiek.u, Warszawa 2006, s. 110-112 i 117-119. 
efekt podpuchnięcia; powiekę górną ostro podcięto. W podobny sposób wystylizowano twarz Dzieciątka.

W przypadku postaci świętej Barbary poza i układ draperii wydaja się nieco sztywniejsze. Święta podtrzymuje ponad prawym biodrem wysoki model wieży, jej prawa ręka, przytrzymująca połę płaszcza po prawej stronie, jest ułożona w geście prezentacji. Opracowanie rzeźbiarskie detali (które można było dokładnie przeanalizować podczas zdejmowania przemalowań w trakcie prac konserwatorskich) zdaje się trochę surowsze, a modelunek - twardszy. W partii ramion z mniejsza pieczołowitościa gładzono powierzchnię, promieniste układy ponad paskiem sa grubiej rzeźbione, krawędź sukni układa się sztywno, a załamania na płaszczu są rzadsze. Twarz cechuje się natomiast podobnym typem urody, choć jej owal jest nieco bardziej zbliżony do trójkąta. I tu mamy do czynienia z wyeksponowaniem nosa i pełnych, mięsistych ust oraz z silnie podpuchniętymi oczyma o małych gałkach, osadzonych płytko, niemal bez oczodołów (końcowy kształt nadawała brwiom zapewne polichromia, jak to jest obecnie). Twarz świętej ujmuja po obu stronach szerokie zakola włosów opadających na ramiona. Pasma włosów wydobyto bardzo schematycznymi, płytkimi drążeniami dłutem łyżkowym (po trzy z każdej strony).

Sposób opracowania odwrocia, zwarte bryły i spłaszczony wolumen figur, z rozwiniętym w płaszczyźnie oglądu kontrapostem, wyraźnie przeznaczonym do oglądu frontalnego, wskazuja, że omówione rzeźby stanowiły niegdyś część średniowiecznej nastawy ołtarzowej, co sugerował już Lemcke $^{34}$. Zapewne był to tryptyk szafiasty o dość płytkiej skrzyni, wypełnionej trzema figurami w układzie asystencyjnym, z Madonną w centrum. O ich przynależności do tego samego retabulum mogą świadczyć zbliżone rozmiary ${ }^{35}$, materiał i techniczny sposób opracowania odwrocia, omówione różnice w opracowaniu formy wskazuja jednak, że nie wyszły one raczej spod tej samej ręki. Wydaje się, iż figury powstały w lokalnym warsztacie pomorskim o średniej klasie artystycznej. Sposobem ujęcia postaci i charakterystyką fizjonomii Maria jest zbliżona przykładowo do nieco wcześniejszej figury Madonny z Dzieciątkiem z Sokolnik w powiecie nowogardzkim, datowanej przez Zofię Krzymuską-Fafius na lata około

34 H. Lemcke, op. cit., s. 356.

35 Madonna z Dzieciątkiem mierzy 95 cm wys., św. Barbara - 93 cm wys. 
$1400 \mathrm{roku}^{36}$. Twórcy rzeźb byli świadomi form stylu pięknego, który uległ tu - jak już wspomniano - daleko idącej schematyzacji ${ }^{37}$.

Moment włączenia obu średniowiecznych zabytków w ołtarz w Boguszynach nie jest znany - zdobiły one nisze retabulum już w czasach Lemckego, a więc ich inkorporacja nastąpiła przed 1906 rokiem. Biorąc pod uwage późny czas wybudowania kościoła (koniec XV wieku), można stwierdzić, że nie pochodziły one z jego pierwotnego wyposażenia, zreszta - jak wyżej wskazano - nie jest pewne, czy protestanckie retabulum powstało właśnie dla tego wnętrza. Panujący na tych terenach obyczaj celowego pozostawiania przez protestantów elementów wyposażenia gotyckiego w pokatolickich świątyniach został przeanalizowany przez Marcina Wisłockiego. Wskazał on na fakt, że pomorscy reformatorzy dokonali reinterpretacji kultu świętych, nie odrzucali czci maryjnej, a dawne figury czy obrazy kultowe niekiedy przez długi okres zachowywały ślady swej niegdysiejszej funkcji, podkreślając ciagłość „obyczaju Kościoła”38. W tym świetle fakt dokonanej w Boguszynach adaptacji nie dziwi, nawet

36 Muzeum Narodowe w Szczecinie. Zob. Z. Krzymuska-Fafius, Plastyka gotycka na Pomorzu Zachodnim. Katalog zbiorów, Muzeum Pomorza Zachodniego, Szczecin 1962, nr kat. 21, s. 47, il. 17a.

37 Nie można wykluczyć, że impulsy artystyczne pochodziły z Pomorza Gdańskiego, co zostało stwierdzone przez Krzymuską-Fafius dla wielu innych dzieł gotyckich z tego terenu (zob. eadem, Kilka pomorskich rzeźb po-premonstratenckich. Prayycaynek do badan sztuki pobrzę̇a Bałtyku 2. połowy XIV wieku, „Rocznik Muzeum Narodowego w Warszawie”, 1992, nr 36, s. 235-256; eadem, Rola zakonów w rozwoju rzę́́by zachodniopomorskiej od pot. XIV do pot. XV wieku, [w:] Sztuka ok. 1400. Materiaty sesji SHS, t. 1, pod red. T. Hrankowskiej, Warszawa 1996, s. 277-279). Trudno jednak na tym etapie badań hipotezę tę podeprzeć konkretnymi analogiami.

38 M. Wisłocki, Średniowieczne dzieła sztuki w ewangelickich kościołach Pomorza w okresie nowosytnym, [w:] Terra transoderana. Sztuka Pomorza nadodrzańskiego $i$ dawnej Nowej Marchii w średniowieczu. Materiaty z seminarium naukowego, poświęconego jubileuszowi 50-lecia pracy w muzealnictwie sžczecińskim Zofii Kryymuskiej-Fafius, 7-8 czerwca 2002, Szczecin 2004, s. 239-251; idem, Sztuka protestancka, s. 237-260. Zob. także na temat nowożytnych losów dzieł średniowiecznych w kościołach na Pomorzu Wschodnim: G. Jurkowlaniec, Medieval Images and Their Early Modern Settings in the Churches of Prussia (1525-1772), [w:] Ecclesiae Ornatae. Kirchenausstattungen des Mittelalters und der frühen Neuzeit zwischen Denkmalwert und Funktionalität („Kunsthistorische Arbeiten der Kulturstiftung der deutschen Vertriebenen”, Bd. 6), Bonn 2009, s. 291-308. Ogólniej na temat funkcjonowania dzieł średniowiecznych w nowym kontekście w okresie nowożytnym 
z punktu widzenia doktryny protestanckiej, tyle tylko, że rzeźby - zepchnięte do bocznych nisz - zostały pozbawione kultowego charakteru. Z drugiej strony fakt, że obie figury są z trudem wkomponowane w swe ramy (nisze są dla nich za wąskie i o wiele za wysokie), wskazuje, iż owa adaptacja nie była zamierzona od początku istnienia protestanckiego retabulum, ale nastąiła później (być może w okresie przekształcania go w ołtarz ambonowy).

W świetle przedstawionych historycznych modyfikacji ołtarza w Boguszynach dzieło to - od zarania protestanckie, przekształcone przez samych protestantów w obiekt nowocześniejszy, adaptujące zabytki pokatolickie, aż wreszcie samo skatolicyzowane - stało się typowym exemplum obiektu o żywym trwaniu w przestrzeni sakralnej.

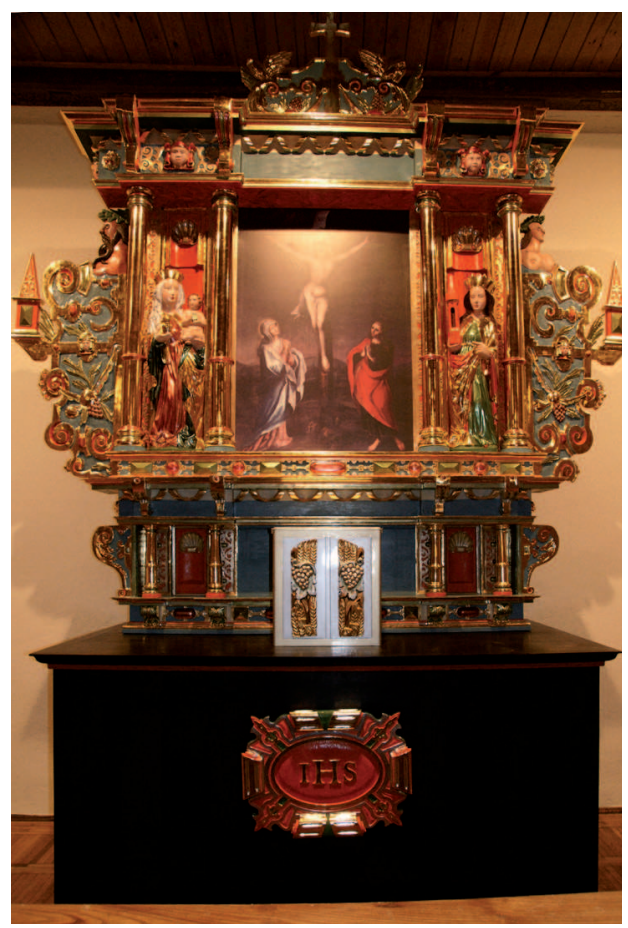

Il. 1. Boguszyny, kościół par. Retabulum ołtarzowe, pierwsza ćw. XVII w. (stan po konserwacji w 2010 r.) (fot. J. Raczkowski)

zob. eadem, Epoka nowożytna wobec średniowiecza. Pamiatki pržeszłości, cudowne wižerunki, drieła sqtuki, Wrocław 2008. 


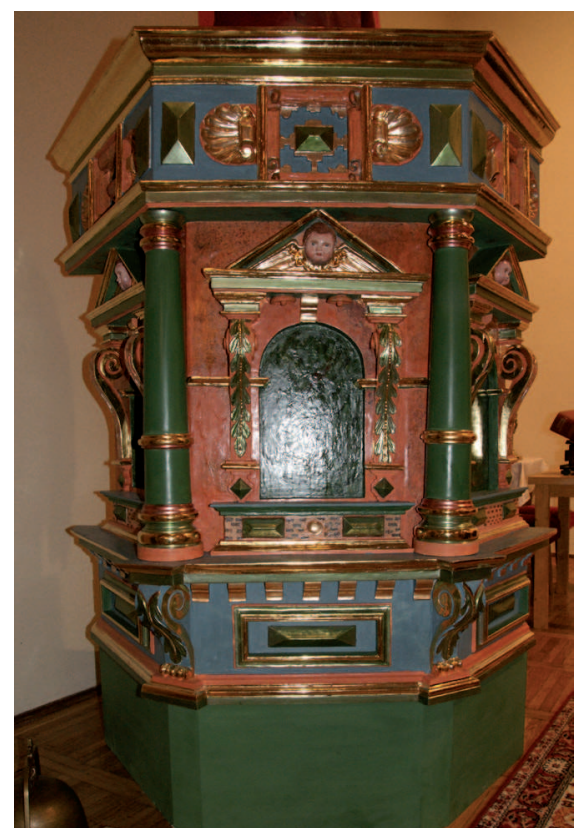

Il. 2. Boguszyny, kościół par. Korpus ambony, pierwsza ćw. XVII w. (stan po konserwacji w 2010 r.) (fot. J. Raczkowski)

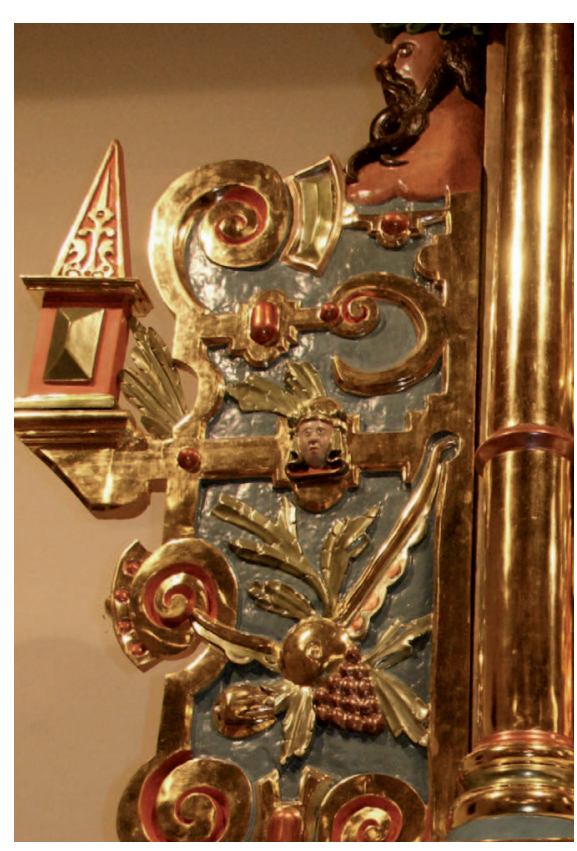

Il. 3. Boguszyny, kościół par. Retabulum ołtarzowe - fragment, uszak boczny, pierwsza ćw. XVII w. (stan po konserwacji w 2010 r.) (fot. J. Raczkowski) 


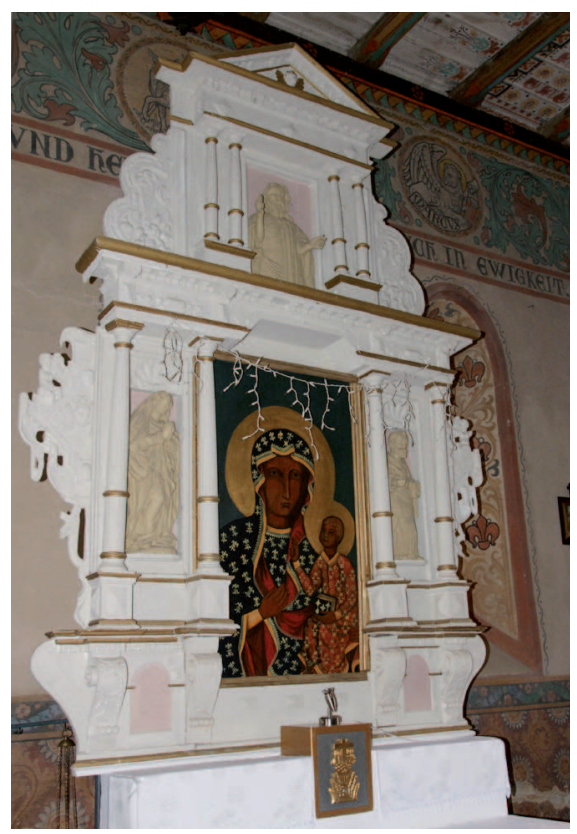

Il. 4. Bolewice, kościół fil. Retabulum ołtarzowe, pierwsza poł. XVII w. (fot. J. Raczkowski)

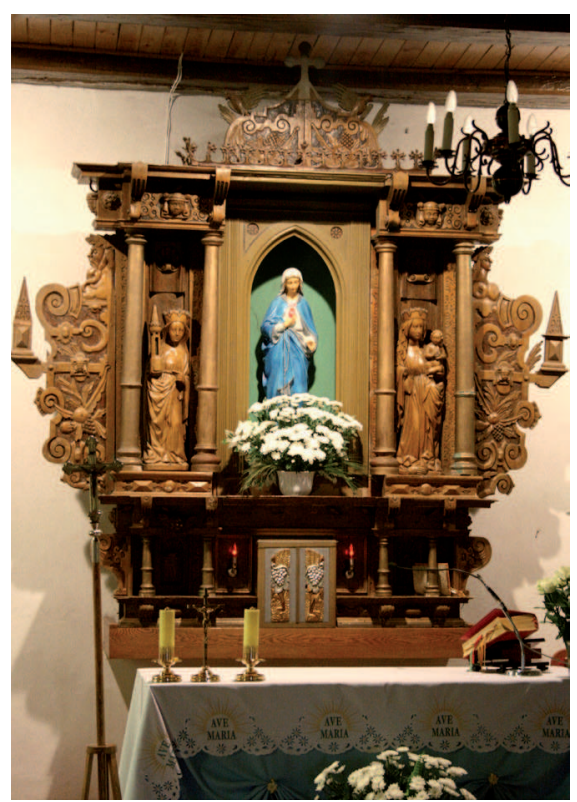

Il. 5. Boguszyny, kościół par. Retabulum ołtarzowe, pierwsza ćw. XVII w. (stan przed konserwacja) (fot. M. Ziemkiewicz) 


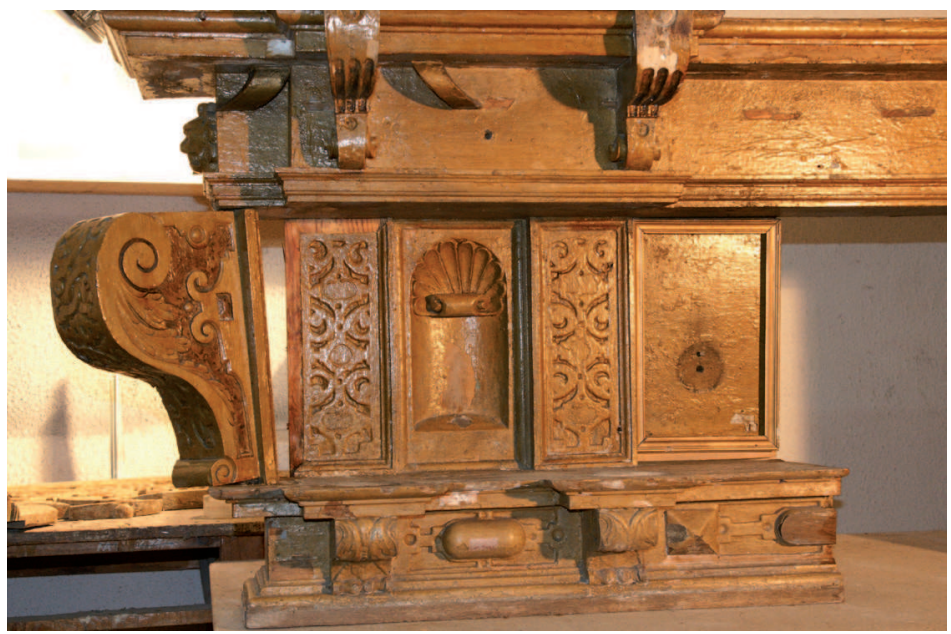

Il. 6. Boguszyny, kościół par. Retabulum ołtarzowe - fragment predelli, pierwsza ćw. XVII w. (stan przed konserwacja) (fot. M. Ziemkiewicz)

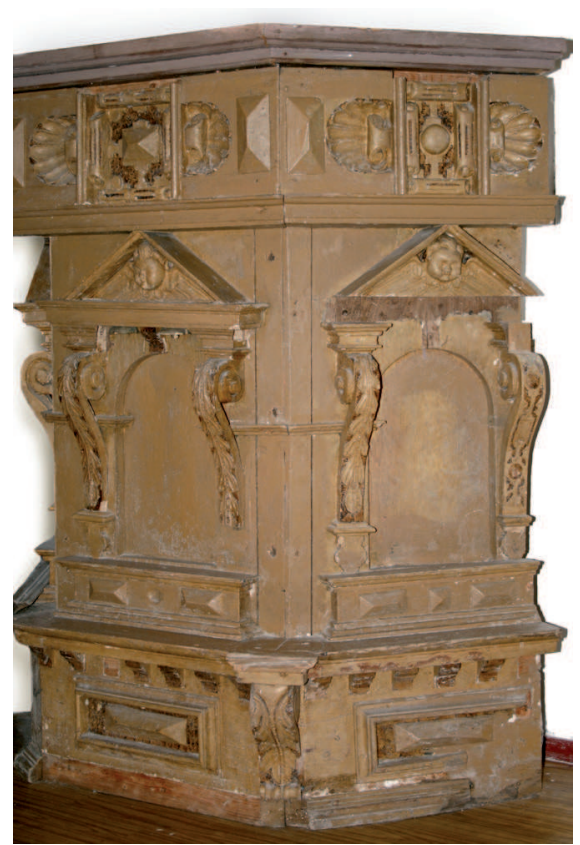

Il. 7. Boguszyny, kościół par. Korpus ambony, pierwsza ćw. XVII w. (stan przed konserwacja) (fot. M. Ziemkiewicz) 


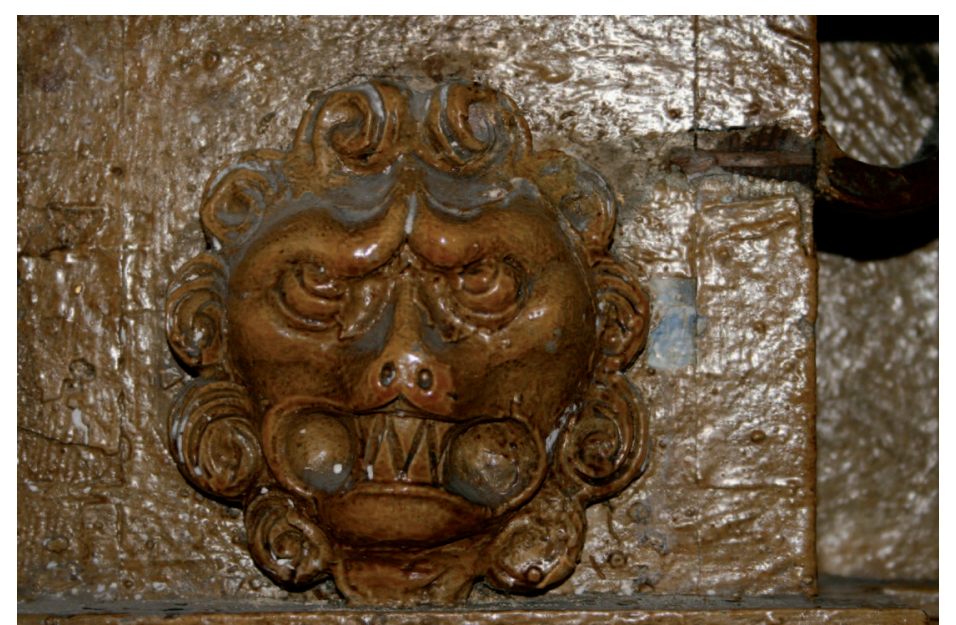

Il. 8. Boguszyny, kościół par. Retabulum ołtarzowe - fragment, maska lwa ze zwieńczenia, pierwsza ćw. XVII w. (stan przed konserwacja) (fot. M. Ziemkiewicz)
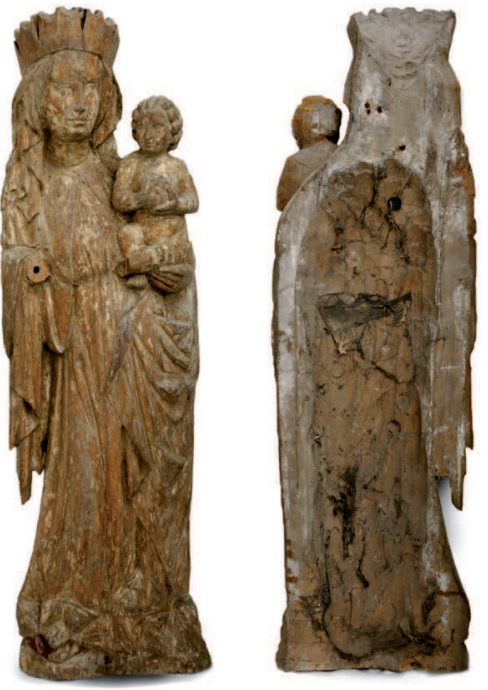

Il. 9. Boguszyny, kościół par. Figura Madonny z Dzieciątkiem (en face i odwrocie), ok. 1430 r. (stan w trakcie konserwacji) (fot. M. Ziemkiewicz)
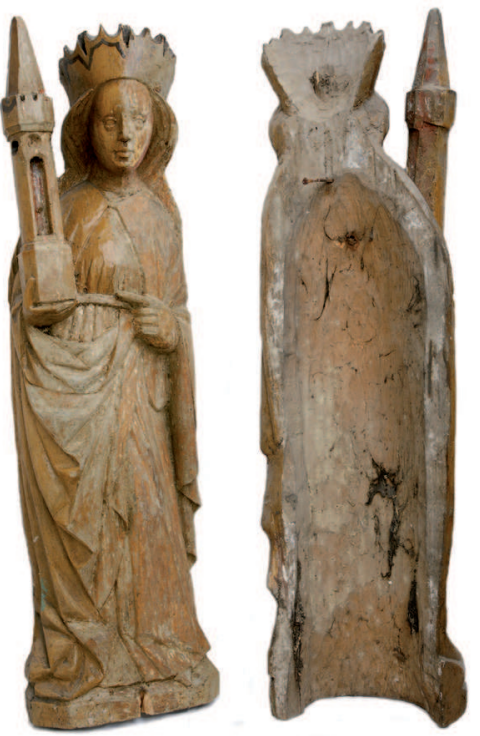

Il. 10. Boguszyny, kościół par. Figura św. Barbary (en face i odwrocie), ok. 1430 r. (stan w trakcie konserwacji) (fot. M. Ziemkiewicz) 


\section{Summary}

\section{Former "pulpit-retable" in the Holy Virgin of Rosary church in Boguszyny in context of recent conservation works}

In the parish church in Boguszyny/Gottberg (commune Pełczyce, district Choszczno) in West Pomerania one can find interesting relics of Lutheran wooden "pulpit-retable," that over the years followed the changing liturgical needs of the religious communities using the church. Despite their early dating and good artistic quality they hitherto escaped the attention of researchers. The present study aims for introducing that historic artefact into the literature as an example of "living" work of art, adjusted to diverse contexts. The opportunity to undertake that subject have been recently performed conservation works (A. Przepióra, M. Ziemkiewicz, Torun 2010), that resulted in recreating the artistic impact obliterated over the centuries.

The main body of the retable and the carcass of the pulpit, decorated in northern renaissance style, had been made in the first quarter of $17^{\text {th }}$ century. The retable made one of the first in West Pomerania examples of an autonomic, Lutheran architectonic retables, liberated from the Mediaeval tradition. Its iconographic program remains unknown (there is an information on a nonexistent relief or The Last Supper in the predella). In the side recesses of the retable sculptures of Virgin with the Child and St. Barbara were placed, originating probably form some Gothic triptych. They in turn make an interesting proof of the activities of local woodcarvers' workshops in the first quarter of $15^{\text {th }}$ century, scarcely represented in this area.

In an unknown circumstances (probably already after 1700) the Boguszyny retable and pulpit had been integrated in the characteristic "pulpit-retable," popular in this area since late $17^{\text {th }}$ century. In such a form it functioned till the World War II. After the church have been taken over by the Catholic church, the retable underwent a number of drastic conversions, that aimed for adjusting it to the new function. In 2010 the conservators were faced with those conversions. The completed conservation works has brought the retable to the condition closest to the original phase (with reconstruction of missing elements of the structure, polychrome and gildings and with stylised arrangement of central quarter), relics of the pulpit were returned to its former function. The performed treatment seems to be a reasonable compromise between the Protestant history 
of the artefact and its present Catholic usus. The present paper, analysing in detail all those transformations, is a contribution to the recently undertaken discussion on the conservation problem of transformed historic monuments and artefacts serving different denominations and on the attitude of contemporary preservation and conservation of monuments towards those transformations. 